Ключевые слова: высшее образование, качество образования, цифровые образовательные технологии, будущий специалист, профессиональная education.

GILTAY L. S. The impact of digital educational technologies on the modern state of higher

The article deals with the influence of digital educational technologies on the current state of higher education. The experience of domestic and foreign researchers in studying the impact of digital educational technologies on the quality of the educational process is analyzed. The article emphasizes that the Strategy for the development of the national education system is adequately shaped by modern integration and globalization processes, it envisages the steady movement and development of Ukraine in the first quarter of the 21 st century, the integration of the national education system into the European and world educational space. The education system requires the training of highly qualified specialists. Many countries are now considering the development of information and communication technology as a key element of basic education. The rapid development of ICTs and their penetration into all spheres of society requires not only increasing the level of computer literacy of graduates of HEI, but the formation of a student's Information and Communication Competence (ICC), which ensures equal participation of a specialist in the global information society and promotes employment opportunities. The formation of CCI students of the HEI, especially pedagogical specialties, is currently one of the most urgent tasks in the higher vocational education system. This is primarily related to international processes: the convergence of Ukrainian higher education with European within the Bologna process, globalization and internationalization of the cultural and information world space. Analysis of vocational education in Ukraine and European countries shows that digital educational technologies are the main leading of the basic components of the training of future computer specialists. The article points out that the rapidly changing environment of higher education, alongside the dynamic and often undefined information ecosystem in which we all work and live, requires new attention to focus on fundamental ideas about this ecosystem. Significant changes related to the formation of a new type of social structure - the information society, mean: knowledge orientation, digital representation of objects, innovative nature and virtualization of production, dynamism of social processes, assessment of the effectiveness of the individual as a person with information and communication technology.

Keywords: higher education, quality of education, digital educational technologies, future specialist, professional activity. with information and communication technology.

DOI: https://doi.org/10.31392/NZ-npu-145.2019.5

УДК 378.091.3:373.5.011.3-051]:78

Дуда І. Т., Ленд’єл-Сяркевич А. А., Сербін М. І.

\title{
ТЕАТРАЛІЗАЦІЯ ЯК ІННОВАЦІЙНА ТЕХНОЛОГІЯ \\ ВИКОНАВСЬКОЇ ІНТЕРПРЕТАЦІЇ У ПРОЦЕСІ ФАХОВОЇ ПІДГОТОВКИ МАЙБУТНІХ УЧИТЕЛІВ МУЗИЧНОГО МИСТЕЦТВА
}

\begin{abstract}
Характерною особливістю сучасної мистецької освіти в Україні стало посилення зв'язків між культурою та освітою, зумовлене тим, що саме культура фокусує систему ціннісних уявлень, які становлять основу
\end{abstract}


особистісних орієнтирів суб’єкта, регулюють його діяльність, визначають спосіб буття. У фрілософрській літературі проблеми удосконалення системи мистецької освіти знайшли широке відображення в працях Т. Андрущенко, В. Біблера, М. Бахтіна, А. Бойка, . Гессена, В. Давидова, М. Євтуха, І. Зязюна, Е. Ільєнкова, В. Лутая, М. Михальченка та багатьох інших.

Упродовж останніх років плідно розробляється гуманітарно-культурна складова сучасної мистецької освіти, зокрема, у працях Л.Горбунової, О. Невмержицького, Г. Падалки, О. Хижної, О. Шевнюк, П. Щербаня та інших [11]. Характерною особливістю сучасного періоду розвитку мистецької освіти $€$ пошук нового змісту і технологій навчання, розгортання експериментальної роботи, спрямованої на впровадження інновацій, а також культурологічна орієнтація навчально-виховного процесу, що передбачає не лише фрормування у студентів певної системи знань умінь та навичок, а й розвиток духовності в контексті гармонійної взаємодії всіх індивідуальних процесів світосприйняття і становлення мистецької освіти як фрактора розвитку культури.

Дух театральності заполонив третє тисячоліття. Він завоював художнє мислення, проявляючи себе в образності мистецьких творів. Як зазначає А. Горбов поняття "театральність" не стало ні науковим терміном, ні самостійною естетичною категорією. Це поняття, частіш за все, вживається в оціночній якості, як своєрідний епітет. У той же час протягом останніх десятиріч "театральним" найчастіше називають все те, що варте похвали і відповідає природі сценічного мистецтва, а, також, масштабність, свого роду "яскравість" художнього узагальнення [5].

У сучасному музикознавстві велика увага приділяється проблемам простору та часу. Значна кількість наукових робіт присвячена саме цим питанням в їх жанрово-стильовому, виконавському та теоретичному аспектах. Такі дослідження подекуди набувають навіть культурологічного чи фрілософрсько-естетичного звучання, але в багатьох із них не застосовується третій, невіддільний від простору та часу, компонент - рух. Сьогодні його вага в формуванні виконавських тенденцій значно більша, ніж раніше. Експерименти з часом та простором поступилися місцем експериментам з рухом, який виступає тут не лише як механістичне явище, але і як філософрська категорія.

Метою статmi є розкриття особливостей театралізації як інноваційної технології виконавської інтерперетації музичних творів.

В понятті "театральність" відображається вплив наочного художнього світу, а слово “театр", яке $є$ складовим компонентом цього поняття, використовується у найширшому, узагальненому і навіть символічному значенні, розкриваючи закономірності та специфріку театрального мислення. Поняття "театральність" породжене впливом видовищних художніх форм театру, кіно, їх естетики і закономірностей, а також впливом режисерської творчості на мистецтво третього тисячоліття.

Мистецтво третього тисячоліття відзначається розвитком синтетичних художніх форм, підсиленням тенденції до взаємопроникнення не лише різноманітних видів мистецтв, але й певним мутаціям в рамках кожного із них. 
На початку культурного розвитку людства мистецтво виникло як засіб спілкування. За умов відсутності сорормованої мови основними засобами спілкування стали звук, ритм та дійство. 3 цієї синкретичної звукопластичної мови ритуалів пізніше виросли макрожанри, а потім і види мистецтва: танець, спів, декламація.

У процесі розвитку людського суспільства різні за своїми властивостями складові первісного прамистецтва поступово відокремлювалися і починали свою власну еволюцію. Саме це відокремлення зумовило активний пошук нових засобів виразності, художніх прийомів, оригінальних підходів. Довгий шлях власного розвитку різних видів мистецтва призвів до високого розквіту кожного з них, до створення багатьох шедеврів літературної, музичної, живописної та хореографрічної творчості.

У XX-му сторіччі ті жанри, що перебували на межі двох чи більше видів мистецтва, почали проникати навіть у найчистіші їхні прояви. В мистецтвознавстві цей період отримав назву “ера синтезу". Але, враховуючи все вищезазначене, мабуть, логічніше буде розглядати процес взаємопроникнення деяких видів мистецтва як повернення до власного синкретичного стану на якісно новому рівні.

Якщо розуміти термін "синтез" як поєднання окремих складових частин, то його вживання в даному контексті не $€$ коректним, оскільки музика та рух в процесі театралізації музичних творів не представляють собою окремі компоненти художньої реальності. Підтвердження цьому знаходимо, наприклад, в історії розвитку музичної культури Єгипту (III-IV тис. до н. е.): “...визначеність і подібність жестів зображених на барельєфах музикантів переконують нас в тому, що вже за чотири тисячі років до н. е. існувала цілком точна “мова жестів", вірніше навіть “малюнок жестів”, яким обов'язково супроводжується вокальне виконання. Якого великого значення надавалося єгиптянами цьому “повітряному письму” видно хоча б з того, що у древньому Єгипті “співати" - означає буквально - “створювати рукою музику ...” [4, с. 51].

Театралізація - це метод художнього осмислення реальних подій та організація сценічної дії . "При цьому не треба забувати, що театр диктує дві головні вимоги: організацію сценічної дії (зорове розкриття драматургічного конфлікту) і створення художнього образу вистави. Ось чому основа театру п'єса, а основа театралізації - сценарій", - зауважує А. Горбов [5]. Тут необхідно зауважити, що сьогодні, як у теоретиків масових театралізованих заходів, так і у практиків немає єдиного загального розуміння сутності театралізації. Вони ще не досліджували і на практиці не перевіряли кордони й принципи її використання, її необхідність і можливості.

Згідно трактовки Є. Назайкінського, музичний твір - це "матеріально зафіксований ідеальний художній об'єкт, що має здатність зберігати свою інваріантну структуру, а разом з тим - завдяки виконавцям, слухачам i конкретним умовам - пристосовуватися до ситуації й історично розвиватися" [8, с. 28]. При цьому результатом матеріальної фріксації музичного твору $\epsilon$ авторський текст. Проте Ю. Кочнєв підкреслює, що не слід плутати авторський текст музичного твору з нотним текстом, який $є$ лише засобом графічного 
закріплення звукового процесу. Авторський текст - це не нотний запис, це сама музика [6, с. 58]. Б. Асаф'єв зауважив, що “Музична інтонація ніколи не пориває зв'язків ні зі словом, ні з танцем, ні 3 мімікою (пантомімою) тіла людського, але "переосмислює" закономірності їхніх фрорм і складових елементів у свої музичні засоби вираження" [2, с. 112].

Як і в давні часи, сучасна система нотації є дуже схематичною. Саме цій її властивості ми маємо бути вдячні за можливість інтерпретувати музичні твори, а не просто їх відтворювати. Завдяки недосконалості нотного тексту виконавці мають простір для власного творчого процесу, спорідненого з композиторським. На думку В. Москаленка, його сутністю $€$ "доосмислення" музичного твору. Він визначає музичне виконання як "вторинне творче становлення музичної образності, результатом якого $є$ втілення в живому звучанні одного з варіантів цілісної сукупності, названої музичним твором" [7, с. 47].

Взагалі поняття синкретичності у процесі трансформації вокального або хорового твору $є$ основоположним. Сприйняття та обробка інформації на кожному етапі інтерпретування супроводжується елементом “доосмислення" матеріалу, а це означає, що наступному учаснику передається не набір якісних рис художнього об'єкту, а сам художній об'єкт як результат єдиного мисленнєвого процесу.

У даному контексті, коли мова йде про колективне виконання твору, схема "композитор - виконавець - слухач" дещо порушується за рахунок включення до неї ще однієї ланки - диригента. Це дуже важливо, оскільки процес інтерпретації в такому випадку ускладнюється.

Розглянемо його схематичну побудову, враховуючи всі моменти переходів ідеального уявлення про музичний твір в його матеріальне втілення, внаслідок чого кожний етап трансформації музичного матеріалу пов'яується зі створенням ідеальної слухової (інтонаційної) моделі твору.

Розвиток творчого процесу починається зі створення ідеальної моделі музичного твору композитором і завершується побудовою ідеального образу твору в уяві слухача. По суті ці явища еквівалентні, за виключенням однієї властивості: перше ми називаємо “ідеальна модель”, оскільки ця структура має певну раціональну спрямованість - перспективу ії передачі наступному учаснику творчого процесу; друге ми називаємо "образ" - він має яскраве емоційне забарвлення і абсолютно закінчену фрорму, не розраховану на подальшу трансформацію.

Результатом аналізу означеної схеми $є$ виявлення низки реальних моделей музичного твору, які виникають у процесі його інтерпретації. Отже, графрічна, пластична та акустична моделі твору. Чим саме є всі ці об'єкти? "Графрічна модель" - поняття просторове, "пластична модель" - категорія руху (до того ж, безперечно, ми маємо на увазі динамічний різновид пластики), що стосується реального звучання музичного твору - це типовий прояв хронотопічного процесу. Таким чином, простір, рух та час виступають визначними категоріями на різних етапах трансформації художнього задуму в реальний музичний твір. Безперечно, хронотопічна сутність музичного матеріалу зберігається протягом всього творчого процесу, але його 
“тривимірність” також не викликає сумнівів.

Як вже було зазначено вище, всі ідеальні слухові моделі мають також і візуальну сторону, що не фіксується жодними засобами. Таким чином, театралізація музичного твору $€$ результатом трактування незафіксованих моторно-пластичних компонентів твору, або ж своєрідним перенесенням категорії руху із сфери ідеального в сферу реального

Більшість вокальних композицій мають в своїй основі літературний текст, тому окрім музичних та візуальних уявлень, у формуванні загального "образу" твору бере участь і вербальна сфера. У зв'язку з цим театралізація може відбуватись двома шляхами:

- виводити на перший план рух, започаткований в самому музичному розвитку (синкретична театралізація);

- реалізовувати рух, закладений в літературному тексті (ілюстративна театралізація).

У кожному окремому випадку ми маємо справу з процесом переведення категорії руху із сфери ідеального в сфреру реального, але характер, властивості цього процесу та його сценічного результату, безперечно, будуть відрізнятись.

Етап створення пластичної моделі твору присутній не лише в тих випадках, коли в творчому процесі бере участь диригент. Існує ще один аспект категорії руху: кожний виконавець обов'язково будує пластично-динамічну модель твору за рахунок саме виконання. Гра на будь-якому інструменті також, як і диригування, $є$ послідовністю певних рухів, що відповідають руху музичному як у часовому (темпо-ритмічному), так і емоційному (тембровому) відношенні.

Взагалі поняття синкретичності в процесі трансформації музичного твору $€$ основоположним. "Музично-звукова "матерія", “форма" для музиканта, композитора завжди інтонаційно змістовна, тобто пов'язується зі складним комплексом уявлень і асоціацій (які найчастіше чітко не усвідомлюються) як специфічно музичних, такі позамузичних" [6, с. 139].

Специфіка хорового співу полягає в тому, що аналогічні по суті процеси приховані від візуального сприйняття слухачами. Мабуть, саме тому виникла необхідність “винести на поверхню” пластико-динамічну модель хорового твору дещо іншими засобами. В цьому контексті стає зрозумілим, чому певні рухи виконують співаки хору, а не спеціальна хореографрічна трупа: в такий спосіб більш яскраво та наочно демонструється саме те поєднання двох типів руху (музичного та пластичного), про яке йшлося вище. В разі, коли вони відтворюються однією людиною, цей синтез набуває певної синкретичності.

Отже, як бачимо, авторський текст складається з багатьох музичних та позамузичних елементів, що поділяються на дві групи: зафіксовані та незафіксовані. Зафіксовані - це ті компоненти художньої моделі твору, які відображені в нотному записі. Незафіксовані - компоненти, що не мають реального вираження. Відтворення зафіксованих компонентів авторської моделі твору і трактування незафіксованих їі елементів, в загальному сенсі, саме і є виконавською інтерпретацією. 
У зв'язку з цим театралізація може відбуватись двома шляхами: виводити на перший план рух, започаткований в самому музичному розвитку (синкретична театралізація); реалізовувати рух, закладений в літературному тексті (ілюстративна театралізація). В кожному випадку ми маємо справу 3 процесом переведення категорії руху із сфери ідеального в сферу реального, але характер та властивості цього процесу та його сценічного результату, безперечно, будуть відрізнятись.

Співак певною мірою повинен бути актором, тобто бути спроможним відтворювати емоційний зміст музичного твору за допомогою міміки, пластики, тембру, але прояви артистизму в хоровому виконавстві були до останнього часу обмежені рамками традицій та вимогами вокальної постановки. Значне зростання професійної майстерності хорових виконавців дозволило багатьом колективам вільно використовувати у своїх виступах елементи сценічного руху, не втрачаючи якості звучання. Звісно, цей фракт не міг спровокувати виникнення цілого напрямку в хоровому виконавстві, але він досить серйозно сприяв захопленню колективів театралізацією музичних творів.

Духовна музика $є$ унікальним, специфічним явищем культури. 3 одного боку, вона є складовою мистецтва як акумулятора чуттєво-емоційного досвіду людства, а з іншого - складовою духовного життя суспільства й окремої людини. Треба відзначити, що духовна музика споконвічно була пов'язана 3 вірою людини у Бога і в цьому плані вона має розглядатись не лише 3 естетичної точки зору, а й з функціональної (як практична реалізація духовних потреб) і філософсько-світоглядної, що відображає уявлення людини про систему світу та її ставлення до Творця. Підписання 5 січня 2018 року у храмі Святого Георгія в Стамбулі Томосу про автокефалію Православної церкви України (ПЦУ) стало ще одним вагомим кроком у позбавленні від зовнішнього тиску і втручання, які були не на користь власної ідентичності нашої церкви. Серед хорових колективів, що плідно працюють у цьому напрямі, назвемо наступні: Національна капела України “Думка" (художнй керівник і головний диригент - Євген Савчук), Національний заслужений академічний український народний хор України імені Григорія Верьовки (головний режисер-диригент Зеновій Корінець), камерний хор “Київ” під орудою Миколи Гобдича, камерний хор “Кредо”, яким керує Богдан Пліш, Державна академічна чоловіча капела імені Л. Ревуцького (художній керівник Юрій Курач) та багато інших.

Висновки. Життя ставить перед учителем нові виклики і приносить нові мистецькі виміри, нові пластичні інтонації. Якщо вчитель музичного мистецтва хоче бути сучасним не лише на сцені, але й у використанні всіх можливостей сучасного музичного мислення, має бачити і підмічати у самій дійсності зародження і розвиток нових “фрарб”, образних ресурсів, застосування інноваційних технологій, серед яких можна назвати технологію театралізації.

Театралізація - це процес реалізації ідеальної слухової, моторикопластичної, графічної або вербальної моделі руху в сценічному виконанні музичного твору, в результаті якого створюється вторинний відносно авторського задуму художній об'єкт, синтетичний за своєю фрормою та синкретичний по суті, оскільки він $є$ продуктом єдиного та неподільного. 
психологічно обумовленого процесу музичної інтерпретації.

Підсумовуючи вище сказане щодо технології театралізації, зазначимо:

- запропонована технологія передбачає визначення завдань, змісту, методів, фрорм організації роботи, умов, витрат часу, проведення аналізу результатів;

- педагогічне керівництво потребує послідовного, поступового та планомірного введення студентів у естетичний світ театралізації на основі їхньої безпосередньої художньо-творчої діяльності;

- обізнаність студентів з театралізацією музичних творів є необхідним компонентом художньо-творчої активності;

- подання знань про театралізацію вимагає опори на доступний для студентів музичний матеріал, встановлення достатнього обсягу та цікавої форми, яка допомогла б засвоювати їх глибоко та емоційно.

\section{Використана література:}

1. Андрущенко В. Світанок Європи. Проблема формування нового вчителя для об’єднаної Європи XXI століття. Київ, 2015.

2. Асафьев Б. Музыкальная форма как процесс. Л., 1971.

3. Бахтин М. М. Собрание сочинений. В 7 т. Т. 1. Философская эстетика 1920-х годов. Москва : Русские словари; Языки славянской культуры, 2003. 958 с.

4. Закс К. Музыкальная культура Египта. Музыкальная культура древнего мира. Л., Музгиз, 1937. C. 46-67.

5. Горбов А. С. Режисура видовищно-театралізованих заходів : посібник. Фастів : Поліфаст, 2004. $264 \mathrm{c}$.

6. Кочнев Ю. Музыкальное произведение и интерпретация. Сов. музыка. 1969, № 12.

7. Москаленко В. Теоретический и методический аспекты музыкальной интерпретации (к проблеме анализа). Исследование. Київ : КГК, 1994.

8. Назайкинский Е. Логика музыкальной композиции. Москва, 1982.

9. Теплов Б. Психология музыкальных способностей. Л., 1960.

10. Падалка Г. М. Педагогіка мистецтва (Теорія і методика викладання мистецьких дисциплін). Київ : Освіта України, 2008. 274 с.

11. Khyzhna O, Lendel-Sarkevich A. (2018). Peace Education as Arts Education: In Search of New Strategies// Philosophy and Cosmology, Volume 21 The Academic Journal ISSN 2518-1866 (Online), ISSN 2307-3705 (Print),P. 74-84.

\section{References:}

[1] Andrushchenko V. Svitanok Yevropy. Problema formuvannia novoho vchytelia dlia obiednanoi Yevropy KhKhI stolittia. Kyiv, 2015.

[2] Asafev B. Muzykalnaya forma kak process. L., 1971.

[3] Bahtin M. M. Sobranie sochinenij. V 7 t. T. 1. Filosofskaya estetika 1920-h godov. Moskva : Russkie slovari; Yazyki slavyanskoj kultury, 2003. $958 \mathrm{c}$.

[4] Zaks K. Muzykalnaya kultura Egipta. Muzykalnaya kultura drevnego mira. L., Muzgiz, 1937. S. 46-67.

[5] Horbov A. S. Rezhysura vydovyshchno-teatralizovanykh zakhodiv : posibnyk. Fastiv : Polifast, 2004. $264 \mathrm{~s}$

[6] Kochnev Yu. Muzykalnoe proizvedenie i interpretaciya. Sov. muzyka. 1969, № 12.

[7] Moskalenko V. Teoreticheskij i metodicheskij aspekty muzykalnoj interpretacii (k probleme analiza). Issledovanie. Kiyiv : KGK, 1994.

[8] Nazajkinskij E. Logika muzykalnoj kompozicii. Moskva, 1982.

[9] Teplov B. Psihologiya muzykalnyh sposobnostej. L., 1960.

[10] Padalka H. M. Pedahohika mystetstva (Teoriia i metodyka vykladannia mystetskykh dystsyplin). Kyiv : Osvita Ukrainy, 2008. 274 s. 
[11] Khyzhna O., Lendel-Sarkevich A. (2018). Peace Education as Arts Education: In Search of New Strategies// Philosophy and Cosmology, Volume 21 The Academic Journal ISSN 2518-1866 (Online), ISSN 2307-3705 (Print), P. 74-84.

ДУДА И. Т., ЛЕНДЬЕЛ-СЯРКЕВИЧ А. А., СЕРБИН М. И. ТеатралИзацИЯ как ИНновацИонНаЯ технология исполнительской интерпретации в процессе профессиональной подготовки будущих учителей музыкального искусства.

В работе рассматриваются особенности внедрения технологии театрализации в прочесс профессиональной подготовки будущих учителей музыкального искусства в вузах, культурологический аспект которой теоретически переосмысливается в условиях изменения образовательной парадигмы.

Ключевые слова: культурологический подход, театрализация, исполнительская интерпретаџия, профессионально-педагогический потенциал, организационно-педагогическая система.

DUdA Y.T., LENDIEL-SIARKEVYCH A. A., SERbYNM. Y. Theatricalization as innovative technology of performance interpretation in the process of professional preparation of future teachers of musical art.

The author of the article considers issues of the category of movement in the field of choral art, dramatization of music as a result of interspecific synthesis of musical interpretation. The problem of methodological change of orientation in future music teachers training is investigated in the context of reformation of modern culturological education. It is important today that the main task of the pedagogical science is to make system of the pedagogical training of future teachers of a music.

Keywords: the culturological approach, the higher educational establishments, the choral music, the cultural environment, the professional and pedagogical potential, organization and pedagogical system.

DOI: https://doi.org/10.31392/NZ-npu-145.2019.06

УДК 378.23 .12

Думко Н. В.

\section{ВРАХУВАННЯ ОСОБИСТІСНИХ ЗАПИТІВ КУРСАНТІВ ПОЛІЦІї НА ПОБУДОВИ ВЛАСНОЇ ТРАЄКТОРІЇ НАВЧАННЯ}

У статі визначено особистісні запити курсантів поліиії на побудови власної траєкторії навчання. Задачі: визначити особливості побудови власної траєкторії навчання; з 'ясувати три основні лінії побудови власної траєкторії навчання курсантів поліиії. Працівник поліиії повинен професійно володіти усіма набутими компетентностями, дотримуватися принципів діяльності поліщії, оцінювати суспільні та економічні явища, виконувати покладені на поліцію завдання, приймати обтрунтовані рімення, поєднувати високий професійний рівень з моральністю $і$ культурою, бути здібним до ділового спілкування. Індивідуальна освітня траєкторія - це персональний шлях реалізаиії особистісного потенціалу кожного курсанта в освіті. Під особистісним потениіалом курсанта тут мається на увазі сукупність його здібностей - діяльнісних, пізнавальних, творчих, комунікативних та інших. Прочес виявлення, реалізачії та розвитку здібностей курсантів відбувається в ході освітнього руху курсанта за 